\title{
An Unusual Wohlfahrtiamagnifica Myiasis Case Localized in Cutaneous and Subcutaneous Tissues in a Patient with Head-Neck Cancer
}

\author{
Baş Boyun Kanserli Hastada Kutaneöz ve Subkutaneöz Yerleşimli Sıradışı \\ Wohlfahrtia magnifica Vakası
}

\author{
Cengiz Çevik¹, Özlem Aycan Kaya², Ercan Akbay¹, Mustafa Özkan³, Ahmet Kahraman³, \\ Murat Uçak ${ }^{3}$ \\ 'Department of Otolaryngology, Faculty of Medicine, Mustafa Kemal University, Hatay, Turkey \\ ${ }^{2}$ Department of Parasitology, Faculty of Medicine, Mustafa Kemal University, Hatay, Turkey \\ ${ }^{3}$ Department of Plastic and Reconstructive Surgery,Faculty of Medicine, Mustafa Kemal University, Hatay, Turkey
}

\begin{abstract}
Auricular tumors constitute $6 \%$ of all head-neck tumors. Malignant tumors of the auricula are generally squamous or basal cell carcinomas. Myiasis rarely occurs in healthy individuals. In general, it is a parasite that is seen in patients with mental retardation or psychiatric disorders, elderly individuals, those with poor self-care and hygiene, and those with immune system disorders. In humans, it is mainly seen in tropical and subtropical regions; however, in rare instances, it may be seen in other regions of the world. In the literature, there are limited numbers of myiasis cases reported from Turkey. In this study, we aimed to present a myiasis case (Wohlfahrtia magnifica) involving cutaneous and subcutaneous tissues with an underlying head-neck cancer, which, to the best of our knowledge, has not been reported before in the literature. (Turkiye Parazitol Derg 2014; 38: 135-7)
\end{abstract}

Key Words: Head-neck cancer, myiasis, wohlfahrtia magnifica

Received: 10.09.2013

Accepted: 25.12 .2013

\section{ÖZET}

Aurikula tümörleri tüm baş-boyun tümörlerinin \%6'sını oluşturur. Aurikula malign tümörleri genellikle skuamöz hücreli karsinom ve bazal hücreli karsinomdur. Myiasis sağlıklı insanlarda nadiren görülür. Genellikle mental retardelerde, psikiyatrik bozukluğu olanlarda, yaşlılarda, kişisel hijien ve özbakımı kötü kişilerde ve immune sistemi bozukluğu olanlarda görülebilen bir parazittir. Myiasis insanlarda özellikle topical ve subtopikal bölgelerde görülür fakat diğer bölgelerde nadiren görülmektedir. Literatürde ülkemizden bildirilen myiasis olgusu çok azdır. Baş boyun bölgesinde ve özellikle de kanser yarasında çok daha nadir görülmektedir. Bu çalışmada bilgimize göre literatürde sunulmamış olan baş boyun kanseri zemininde gelişen ve deri ve deri altı dokuları tutan myiasis (Wohlfahrtia magnifica) olgusunu sunmayı amaçladık. (Turkiye Parazitol Derg 2014; 38: 135-7)

Anahtar Sözcükler: Baş-boyun kanseri, myiasis, wohlfahrtia magnifica
Geliş Tarihi: 10.09.2013
Kabul Tarihi: 25.12.2013

Address for Correspondence / Yazışma Adresi: Dr. Cengiz Çevik, Mustafa Kemal University, Department of Otolarygology, Hatay, Turkey. Phone: +90 3262291000 E-mail: drccevik@yahoo.com DOI:10.5152/tpd.2014.3353

CCopyright 2014 Turkish Society for Parasitology - Available online at www.tparazitolderg.org

CTelif hakkı 2014 Türkiye Parazitoloji Derneği - Makale metnine www.tparazitolderg.org web sayfasından ulaşılabilir. 


\section{INTRODUCTION}

Malignant tumors of the auricula are generally squamous (SCC) or basal cell carcinomas (BCC) $(1,2)$. Rarely, malignant skin tumors may also be seen, particularly in the elderly population, who are exposed to sunlight for longer periods. Myiasis is a pathological condition that occurs as a result of infestation of live or necrotic tissues or organs in humans and vertebrates by fly larvae (3). However, myiasis, which occurs during the larval developmental stage of flies, is rarely seen in tumor tissues and/or infected tissues due to factors related to the parasite and host-e.g., in cases of poor hygiene, diabetes mellitus, and immune suppression (4). Although myiasis is mainly seen in tropical and subtropical regions in humans, it can rarely be seen in other regions of the world. Myiasis infestations are classified according to the infected area of the host (anatomical classification) and level of parasitism. In the anatomical classification, myiasis is classified as cutaneous, cavitary (oral, nasal, otomyiasis, intestinal, or urogenital), and ocular myiasis (5). Myiasis is also classified as obligatory, facultative, incidental, or accidental. In the literature, there are several published articles reporting myiasis in different areas of the body, including nasal sinuses, oral cavity, tissues around tracheostomy, and ear $(6,7)$. However, the number of the myiasis cases with an underlying head-neck cancer is very limited. In this study, we aimed to present a myiasis case that developed on a background of a recurrent malignant auricular tumor.

\section{CASE REPORT}

An 87-year-old man underwent surgery with a diagnosis of auricular SCC in a distinct facility. The patient, who did not regularly attend control visits, presented to our clinic with discharging, foul-smelling, ulcerated swelling that extended from the left temporal region to the zygomatic and buccal regions about 1 year after surgery (Figure 1). The patient reported that he had this complaint for approximately 1 month and did not present to an expert. An ulcero-vegetating, brisk mass lesion consistent with recurrence, which was fixed to surrounding tissues, was detected in the physical examination. Maggots were removed from the cancerous wound (Figure 2). On the cranial and temporal CT scans, it could be seen that the mass lesion extended to the intracranial region, from which maggots were removed using a punch (Figure 3). The patient could not be operated on due to his general health conditions and due to the consideration that metastases could not be completely removed; thus, he was referred to an oncology department. Maggots found in the cutaneous and subcutaneous levels of the cancer wound were removed and placed into $70 \%$ ethanol solution for taxonomic evaluation.

\section{Parasitological Evaluation}

The larvae were dissected and identified as Wohlfahrtia magnifica under light microscopy (Olympus SZ-11, Olympus, Tokyo, Japan) (Figure 4). We removed nearly 25-30 maggots from the cancer wound. The maggots were identified as third-stage larvae of Wohlfahrtia magnifica.

\section{DISCUSSION}

Myiasis is rarely seen in healthy individuals. It is commonly seen in patients with mental retardation or psychiatric disorders, elderly individuals, those with poor self-care and hygiene, and those with immune system disorders (8). In our case, the patient

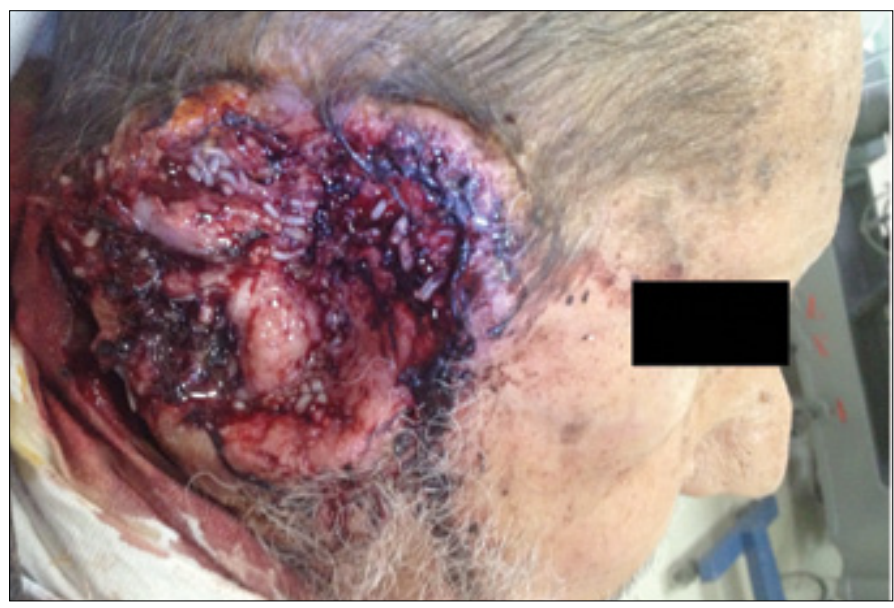

Figure 1. Gross appearance of the tumor (maggots can be seen within the necrotic tissue)

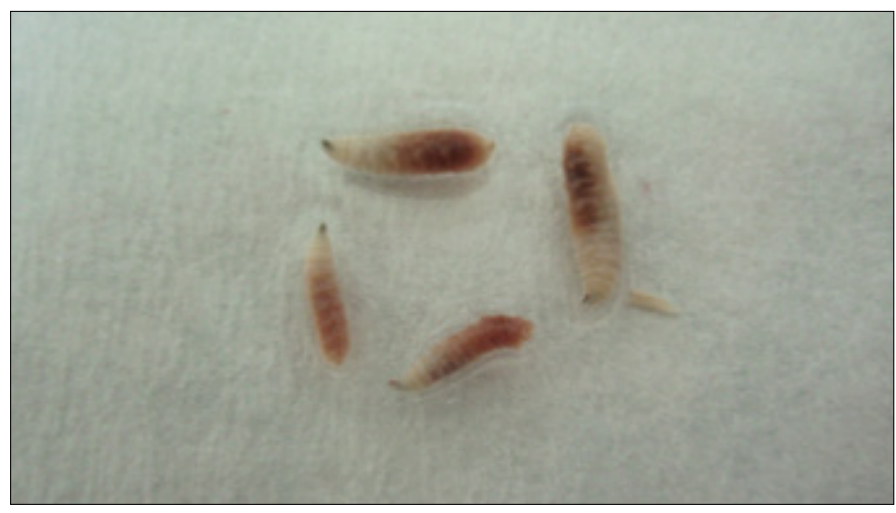

Figure 2. Gross appearance of the parasite

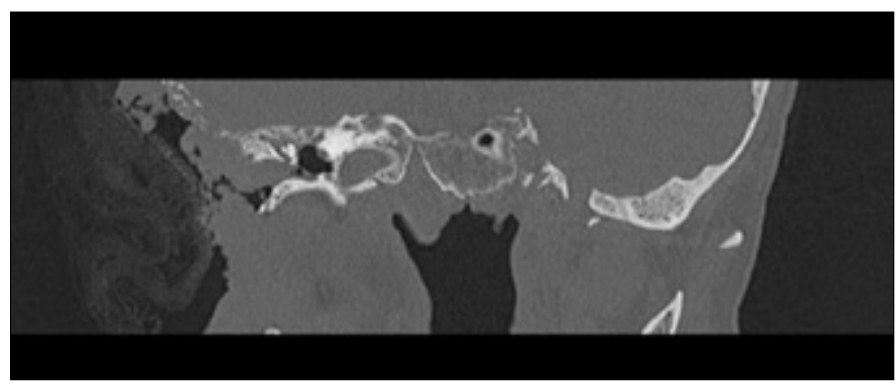

Figure 3. Temporal CT image of the patient

was an elderly individual with a head-neck cancer. Dermal myiasis is one of the most commonly seen forms of myiasis, which is sub-classified into wound, dermal, and abscess-like forms. Our case is a cutaneous myiasis that developed over an underlying cancerous wound.

There are several reports in the literature regarding the head-neck localization of myiasis $(6,7)$. To the best of our knowledge, there is only one case in which myiasis developed over an underlying head-neck cancer (3). Our case is the first in the literature in which cutaneous and subcutaneous myiasis caused by Wohlfahrtia magnifica developed over an underlying head-neck cancer.

In Turkey, there are few reported studies on myiasis cases. Bayındır et al. (7) reported the only known case in the country of Wohlfahrtia 


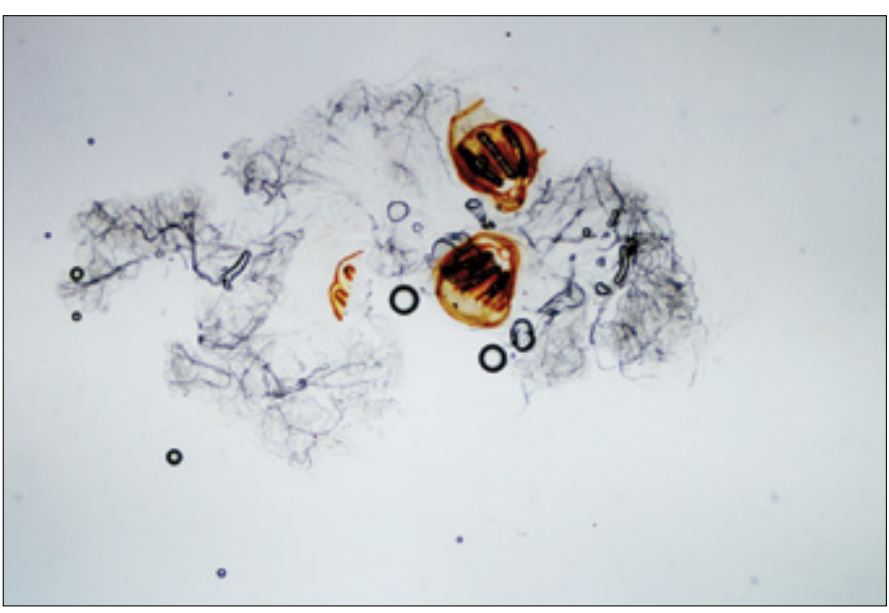

Figure 4. Light microscopic appearance of the posterior spiracular plates of Wohlfahrtia magnifica

magnifica myiasis, which developed over underlying chronic suppurative otitis media. Tuygun et al. (8) reported a cutaneous myiasis case in an 8-year-old boy with hypereosinophilia who had swelling at the right axillary region. Kokcam et al. (9) reported a myiasis case in the frontal-temporal region of a 46-year-old man with a nevoid basal cell carcinoma.

Myiasis species that involve both human and animals include Sarcophagidae, Oestridae, and Calliphoridae. Wohlfahrtia magnifica, presented here, is the only obligate parasite that is able to survive on humans in Turkey. This parasite belongs to the Sarcophagidae family and is generally seen in tropical and subtropical regions (3). This agent is frequently found in wound myiasis seen in the Mediterranean basin, South Russia, Turkey, Israel, and the Middle and Far East regions.

Sesterhenn et al. (10) reported a myiasis case caused by Lucilia species (Calliphoridae) around the site of tracheostomy in a patient with recurrent oropharyngeal cancer. Rubio et al. (11) reported a cutaneous myiasis caused by Chrysomya species in an elderly patient with larynx cancer.

Nagy et al. (12) reported two myiasis cases in patients with a cancer in the urogenital region. Joove et al. (13) reported a myiasis case caused by Lucilia sericata in a 77-years old man with maxillary tumor.

\section{CONCLUSION}

In this study, we aimed to present a case of myiasis caused by Wohlfahrtia magnifica involving cutaneous and subcutaneous tissues of an underlying head-neck cancer, which, to the best of our knowledge, has not been reported before in the literature.

Ethics Committee Approval: Ethics committee approval was not received due to the retrospective nature of this study.

Informed Consent: Written informed consent was obtained from patients who participated in this study.

Peer-review: Externally peer-reviewed.

Author Contributions: Concept - C.C., O.A.K.; Design - C.C., E.A.; Supervision - C.C.; Funding - C.C., E.A.; Materials - M.O., A.K.; Data Collection and/or Processing - C.C., M.U.; Analysis and/or Interpretation - C.C., O.A.K.; Literature Review - C.C.; Writing - C.C.; Critical Review - C.C.

Conflict of Interest: No conflict of interest was declared by the authors.

Financial Disclosure: The authors declared that this study has received no financial support.

Etik Komite Onayı: Çalışmamızın retrospektif tasarımından dolayı etik komite onayı alınmamıştır.

Hasta Onamı: Yazılı hasta onamı bu çalışmaya katılan hastalardan alınmıştır.

Hakem değerlendirmesi: Dış bağımsız.

Yazar Katkıları: Fikir - C.C., O.A.K.; Tasarım - C.C., E.A.; Denetleme - C.C.; Kaynaklar - C.C., E.A.; Malzemeler - M.O., A.K.; Veri toplanması ve/veya işlemesi - C.C., M.U.; Analiz ve/ veya yorum - C.C., O.A.K.; Literatür taraması - C.C.; Yazıyı yazan - C.C.; Eleştirel İnceleme - C.C.

Çıkar Çatışması: Yazarlar çıkar çatışması bildirmemişlerdir.

Finansal Destek: Yazarlar bu çalışma için finansal destek almadıklarını beyan etmişlerdir.

\section{REFERENCES}

1. Barr DM. Temporal bone carcinoma. Otolaryngol Clin N Am 2001; 34: 1197-218. [CrossRef]

2. Balough B, O'leary MJ, Martin PJ. Basal and Squamous Cell Carcinoma of the Auricle. In: Jackler RK, Driscoll CLW eds. Tumors of the Ear and Temporal Bone, Philadelphia, Lippincott; 2000. p. 29-55.

3. Bayindir T, Cicek MT, Atambay M, Kizilay A. Cutaneous myiasis in a malignant wound of the head and neck region. J Craniofac Surg 2012; 23: 19-20. [CrossRef]

4. Verettas DA, Chatzipapas CN, Drosos Gl, et al. Maggot infestation (myiasis) of external fixation pin sites in diabetic patients. Trans $\mathrm{R}$ Soc Trop Med Hyg 2008; 102: 950-2. [CrossRef]

5. Yazar S, Dik B, Yalçin S, Demirtaş F, Yaman O, Oztürk M, Sahin I. Nosocomial Oral Myiasis by Sarcophaga sp. in Turkey. Yonsei Med J 2005; 46: 431-4. [CrossRef]

6. Prasanna Kumar S, Ravikumar A, Somu L, Vijaya Prabhu P, Mundakannan Subbaiya Periyasamy Subbaraj R. Tracheostomal myiasis: a case report and review of the literature. Case Rep Otolaryngol 2011; 2011: 303510.

7. Bayindir T, Miman O, Miman MC, Atambay M, Saki CE. Bilateral aural myiasis (Wohlfahrtia magnifica): a case with chronic suppurative otitis media. Turkiye Parazitol Derg 2010; 34: 65-7.

8. Tuygun N, Taylan-Ozkan A, Tanir G, Mumcuoğlu KY. Furuncular myiasis in a child caused by Wohlfahrtia magnifica (Diptera: Sarcophagidae) associated with eosinophilia. Turk J Pediatr 2009; 51: 279-81.

9. Kokcam I, Saki CE. A case of cutaneous myiasis caused by Wohlfahrtia magnifica. J Dermatol 2005; 32: 459-63.

10. Sesterhenn AM, Pfützner W, Braulke DM, Wiegand S, Werner JA, Taubert A. Cutaneous manifestation of myiasis in malignant wounds of the head and neck. Eur J Dermatol 2009; 19: 64-8.

11. Rubio C, Ladrón de Guevara C, Martín MA, Campos L, Quesada A, Casado M. [Cutaneous myiasis over tumor-lesions: presentation of three cases]. Actas Dermosifiliogr 2006; 97: 39-42. [CrossRef]

12. Nagy $V$. Unusual presentation of the urogenital myiasis caused by Luciliasericata (Diptera: Calliphoridae). Ann Agric Environ Med 2012; 19: 802-4.

13. Joo CY, Kim JB. Nosocomial submandibular infections with dipterous fly larvae. Korean J Parasitol 2001; 39: 255-60. [CrossRef] 